\title{
Skin conductance as pain indicator in newborns: a comparison study with heart rate, oxygen saturation and pain behavioral scales
}

Condutância da pele como indicador de dor em recém-nascidos: um estudo comparativo com frequência cardíaca, saturação de oxigênio e escalas comportamentais de dor

José Alfredo Lacerda de Jesus

Faculdade de Medicina, Universidade de Brasília (UnB), Brasília DF, Brazil. Área da tese: Neurociências

Orientador: Professor Dioclécio Campos Júnior

Coorientadora: Professora Rosana Maria Tristão

Correspondence: José Alfredo Lacerda de Jesus; SMPW Quadra 21 / Conj. 2 / Lote 11 / Casa C; 71745-102 Brasília DF - Brasil; E-mail: jalfredo.jesus@gmail.com / alfredo@unb.br

Received 12 February 2013; Received in final form 21 March 2013; Accepted 28 March 2013.

\begin{abstract}
Introduction: Heart rate (HR), oxygen saturation (OS) and skin conductance activity (SCA) are physiological markers of acute pain. Neonatal Facial Coding System (NFCS), Neonatal Infant Pain Scale (NIPS) and modified COMFORT are validated pain behavioral scales. Objective: It was to compare whether the scores of these measures fit the psychophysical parameters for a pain marker (intensity, reactivity, direction, regulation and slope). Method: Observational prospective study including 41 newborns, in which it were compared the maximum HR, the minimum OS, the SCA variables number of waves per second (NWps) and relative area under the curve of waves (AUC), and the scores of behavioral pain scales in the periods before, during and after heel prick. Results: The parameters intensity and regulation were significant for the NWps $(p<0.01)$, AUC $(p<0.05)$, HR ( $p<0.01)$, OS ( $p<0.01)$, NFCS ( $p<0.01)$, NIPS $(p<0.01)$ and modified COMFORT ( $p<0.01)$. The reactivity and direction parameters were significant for all variables (all $p<0.01$ ), except to AUC ( $p>0.05$ ). The slope was significant for the minimum OS and NIPS and modified COMFORT scales ( $p<0.05)$. Conclusion: The responses of SCA, HR, OS and behavioral pain scales are similarly in acute painful events. They fit the psychophysical parameters of a pain marker and serve as measures for pain diagnostic.
\end{abstract}

Key words: pain behavioral markers, pain physiological markers, psychophysical parameters, skin conductance, newborn. 